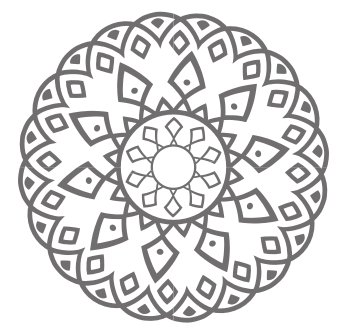

\title{
Religious, Economic, and Political Values Shifting in Inheritance System of SUKU ANAK DALAM
}

\author{
Dian Mustika \& Wenny Dastina
}

\begin{abstract}
Abstrak: Suku Anak Dalam dikenal sebagai kelompok masyarakat terasing di Jambi. Mereka menganut kepercayaan animisme dan dinamisme. Namun, dalam beberapa dekade terakhir, Suku Anak Dalam telah melakukan konversi agama menjadi Islam. Artikel ini mengkaji tentang bentuk pergeseran sistem kewarisan ini serta faktor-faktor yang mempengaruhinya. Penelitian ini menggunakan analisis kualitatif dalam perspektif normatif-sosiologis. Sementara itu, pengumpulan data dilakukan melalui wawancara, observasi, dan dokumentasi. Hasil penelitian ini menunjukkan bahwa dalam praktiknya, berlaku dualisme hukum, yaitu hukum waris Islam dan hukum waris adat. Namun, penggunaan hukum waris adat terlihat lebih dominan dibandingkan hukum waris Islam. Selanjutnya, pergeseran sistem kewarisan, di antaranya terlihat pada proses pewarisan hingga perubahan bentuk dan penggolongan harta waris. Terjadinya pergeseran nilai ini dipengaruhi oleh beberapa faktor, di antaranya: konversi agama, interaksi sosial dengan pendatang, dan migrasi ke wilayah lain.
\end{abstract}

Kata kunci: pergederan, nilai social, warisan, Suku Anak Dalam 
Abstract: Suku Anak Dalam is known as an isolated community in Jambi, adhering to animism and dynamism. However, in the last few decades, some of the Suku Anak Dalam people have converted to Islam. This article examines the changes in the inheritance system, and factors influencing them. This study uses qualitative analysis with a socio-legal perspective. Data was collected through interviews, observation, and documentation. The result reveals that, in practice, the use of customary inheritance law seems to be more dominant than Islamic inheritance law. Furthermore, the shifting in the inheritance system could be seen in the inheritance distribution methods and inheritance classification. These changes are influenced by the religious conversion, social interaction with incomers, and their migrations to other regions.

Keywords: shift, social values, inheritance, Suku Anak Dalam 


\section{Introduction}

Inheritance law is a vital element in social life because of its direct implications for the permanence of the social system, both at the level of family, close relatives, and society in general. This is in line with Amir Syarifuddin's opinion that of all applicable laws in society — the marriage and inheritance law-determine and reflect the family system, and at the same time, a part of civil law. The importance of such inheritance regulation can be seen from its existence in almost all indigenous societies, which have their own inheritance system (Tarigan, 2014: 199).

Inheritance law application in Indonesia refers to three applicable legal systems. These systems are 1) the Western (European) civil inheritance system contained in BW or Civil Code; 2) the customary law system which is influenced by ethnic forms and existing in various areas of the customary law environment; 3) the Islamic inheritance law system, which also consists of various kinds of streams and understandings. However, the plurality of inheritance law often causes problems in its application.

Problems related to the implementation of Islamic inheritance law are found in various regions in Indonesia. It is undeniable that the dualism of inheritance law between customary and Islamic inheritance law often leads to a dilemma because the distribution of inheritance is related to a social identity that is relatively important and complicated. Likewise, this happens in the application of the inheritance system among the Muslim community of Suku Anak Dalam.

One of the characteristics of customary law, including customary inheritance law, is its dynamic. This means that it can change from time to time following the development of the community, and can also differ from one place to another in line with the culture of each community. This is in line with Eugen Ehrlich's argument, stating that the center of legal development activities is not located in the law, jurisprudence, or court decisions, but in the community itself (Ali, 2012: 424).

The changes that occur can be related to social values, patterns of behavior, organizations, social institutions, layers of society, power and authority, and others. According to Samuel Koenig, social change refers to modifications in the patterns of human life that occur due to internal and external causes (Soekanto, 2009: 262-263). 
Soerjono Soekanto stated that the factors causing social and cultural changes include 1) increasing or decreasing of population; 2) discoveries; 3) community conflicts; 4) the occurrence of rebellion or revolution (causes originating from the natural physical environment that surrounds humans, warfare, and the influence of other people's cultures). Meanwhile, the factors driving the process of change can take the form of a) contact with other cultures; b) an advanced formal education system; c) an attitude of respecting one's work and desires to progress; d) tolerance; e) an open system of society; f) a heterogeneous population; g) public dissatisfaction with specific areas of life; h) future orientation; and i) the value that humans should always endeavor to improve their lives (Soekanto, 2009: 275-288).

Furthermore, specifically in the area of customary law, including in the field of inheritance, Runtung Sitepu stated that the factors that caused the shift are, among others: first, the entry of religious elements, especially Islam. Second, there is a shift in family life from extended family life (kinship) toward the prioritization of the interests of the nuclear family life. Thus, this affects the husband and wife's view of the position of their wealth in marriage. Third, there is progress in the field of education, where men and women have the same opportunity to study and work in the community. In this case, a wife's participation in obtaining wealth is even more significant, sometimes even exceeding her husband. Fourth, advances in transportation technology have made the population mobility faster. The last one, the fifth is advances in information technology (Rimawati, 2015: 3).

The development of society, which think modernly causing a shift in life patterns, occurs not only in urban areas but also in villages that still hold fast to the conventional system. This shift in inheritance pattern has also occurred among Suku Anak Dalam community.

Suku Anak Dalam, also known as Orang Rimba, is one of the isolated tribal groups in the Sumatera region. Orang Rimba is spread in the provinces of Jambi, South Sumatra, and Riau. However, the highest number of Suku Anak Dalam is in Jambi Province. As a literary community, Suku Anak Dalam has many traditions that have similarities with the Malay community. Those traditions become their guideline in the social community (Sager, 2008: 5) and (Hidayati, 2016: 151-152). 
Genealogically, Suku Anak Dalam in Jambi Province comes from three descendants, namely: 1), descendants from South Sumatra who generally live in Batanghari district; 2) descendants from Minang Kabau who generally live in Bungo district, Tebo district, Mersam and Batanghari district; and 3) the descendants of the original ethnic Jambi who live in Air Hitam area of Sarolangun district (Mailinar and Nurdin, 2013: 253).

At present, Suku Anak Dalam community, which belongs to the sedentary category, has experienced a religious conversion, from animism and dynamism to Islam. Such conversion has occurred in Suku Anak Dalam in the villages of Nyogan, Markanding, Bunut, Nagosari and Mestong in Muaro Jambi Regency; Air Hitam Village Sarolangun District, as well as in Jebak, Batu Hampar, Singkawang Baru, and Mersam areas in Batanghari District. However, this religious conversion does not apply to Suku Anak Dalam that fall under the category of wandering or nomadic. They still adhere to the belief of polytheism (Mailinar and Nurdin, 2013: 253).

Changes of residence are one of the causes of religious conversion of Suku Anak Dalam. This is because they tend to follow the majority religion of the people around them. These are three factors that encourage religious conversion: 1) adaptation to be applied to external life; 2) the impact of the spread of Islam or Christian missionaries, and 3) the requirement to fill the column of faith in the National Identity Card (KTP) as a prerequisite for obtaining facilities and development programs. The citizens must choose one of six recognized religions in Indonesia. The same thing also happened to the Orang Rimba community who converted to the majority Malay religion in Jambi, which is Islam (Sagala et al., 2018: 243). Much attention is paid to various aspects of the life of Suku Anak Dalam. However, no one has considered the shift in social values in their inheritance system. Several studies related to Suku Anak Dalam include Reslawati's research on the Dinamika Perkembangan Sistem Kepercayaan Suku Anak Dalam (Dynamics of the Development of Suku Anak Dalam Belief System), suggesting that the development of Suku Anak Dalam beliefs has changed, from not having a religion to being a Muslim and Christian. Nevertheless, this has not yet embraced the entire Suku Anak Dalam (Reslawati, 2011). Furthermore, Mitra Roma Yunita and Yohanis Franz 
La Kahija highlighted Makna Menjadi Muslim (the Meaning of Being Muslim) for Suku Anak Dalam who had embraced Islam. For them, being a Muslim is based on the need for security, self-change, and personal expectations because every subject has a desire for a safer life by embracing a religion (Yunita and La Kahija, 2014).

In terms of the religious life of Suku Anak Dalam, Mailinar and Bahren Nurdin concluded that Suku Anak Dalam in Senami III Jebak Batanghari Village, who had embraced Islam, considered Islam to be in harmony with Suku Anak Dalam seloko tradition. However, their conception of Islam is still mixed with traditional beliefs manifested in various religious rituals such as tablilan and basale (Mailinar and Nurdin, 2013). Likewise, in Suku Anak Dalam's marriage and divorce system, Rahmi Hidayati stated that there has been a shift in the system of family law in Suku Anak Dalam, both before and after conversion to Islam (Hidayati, 2016).

From the background above, it is necessary to study the shifting of social values in the inheritance system of Suku Anak Dalam.

\section{Discussion}

\section{The Conception of Social Change}

In life, society must experience changes. In a static society, the change experienced is very little and runs slowly. Whereas in a dynamic society, it experiences a variety of rapid changes. Those changes can be related to social values, behavioral patterns, organizations, social institutions, layers of society, power and authority, and others. William F. Ogburn tried to give a particular understanding, even though he did not define social changes. He stated that the scope of social changes includes elements of material culture towards unnecessary elements. Meanwhile, Gillin and Gillin said social changes as a variation of ways of life accepted, both because of changes in geographical conditions, material culture, population composition, and ideology or because of diffusion or discoveries in society. In short, Samuel Koenig said that social change refers to modifications that occur in the patterns of human life that occur due to internal and external causes. (Soekanto, 2009: 262-263).

Bruce J. Cohen distinguishes between social change and cultural change. According to him, cultural change leads to changes that occur 
in the culture of a society. In contrast, social change is a change that occurs in the structure of society or social organization. In line with the opinion of Cohen, Rogers et al. stated that social change is a process that issues various changes in the structure and function of the social system. At the same time, Soerjono Soekanto, defined social change while also highlighted the consequences arising from these changes. According to him, social change is any change that occurs in social institutions that affect the social system, including values, attitudes, and patterns of behavior between groups in society (Soekanto, 2009: 263).

There are several concepts needed to analyze the process of shifting society and culture, which are commonly called social dynamics, namely: internalization, socialization, and enculturation. The internalization process is a long process that starts from the time an individual is born until he/she almost dies. The individual learns to instill all feelings, desires, passions, and emotions in his/her personality used to develop an individual personality. However, the appearance and activation of various kinds of personality contents are greatly influenced by a variety of stimulation in nature, social environment, and culture around it. Furthermore, in the process of socialization, an individual learns patterns of action in interaction with various individuals around him who occupy various social roles in daily life. Individuals from different societies will experience a different socialization process because it is determined by the structure of the culture and social environment concerned. In contrast, the process of enculturation (civilization) is the process of an individual studying and adjusting his/her thoughts and attitudes to customs, norm systems, and rules that live in their culture. This is no different from the process of internalization and socialization, the enculturation process also starts from childhood and begins from the family environment to friends and those around him/ her (Soekanto, 2009: 263).

The social change basically can be seen, both concretely and abstractly. Concretely, social change can be seen and felt physically. Whereas in the abstract, social change can be felt but cannot be measured. Therefore, to know the occurrence of social change, it is necessary to have characteristics. According to Soerjono Soekanto, there are several characteristics of social change. First, there is no community group that stops developing because change must be experienced by every 
community, either fast or slow. Second, changes will follow changes that occur in particular social institutions. Third, usually changes that occur very quickly will result in disorganization; Fourth, a change cannot be limited to material or spiritual aspects only. Fifth, typological social changes can be categorized as: 1) social processes, which involve the circulation or rotation of the rewards of facilities and individuals who occupy certain positions on a structure; 2) segmentation, which is the existence of units structurally does not differ qualitatively from the existence of each of these units; 3) structural change, namely the emergence of new complexities qualitatively regarding the roles of the organization; 4) changes in group structure, i.e. changes in group composition, level of group awareness and relationships among groups in society (Martono, 2014: 13).

Social change does not just happen. In general, the causes of social change in a society can be classified into two factors, namely, internal and external factors. Internal factors of social change include increasing or decreasing population. Changes in terms of the population may be related to changes in the composition of the population based on age, sex, job, ethnicity, social class, and other variables, as well as the distribution of population which includes changes in population. All of this, of course, contributes to changes in the culture and social structure of society. Second, there are discoveries. The emergence of an invention (innovation) can be one of the causes of social change, even an important concept. Innovation becomes a process of significant social and cultural change, but it takes place in the short term. Innovations can be divided into discoveries and inventions. The series of discoveries and inventions will be even more significant if the inventors produce more cultural elements (Boty, 2015: 38). Third, conflicts are caused by social inequality and differences in interests. According to Marx, conflicts within groups and social classes can bring about the next change.

As a consequence, the occurrence of specific changes shows the success of the winning social group to impose its desires on other social groups or classes. The conflict among groups may occur between the older generation and the younger generation. Such contradictions are common in developing societies from the traditional to the modern stage. Such circumstances lead to specific changes in society. Fourth, 
there is a revolt or revolution. This factor is very closely related to the previous factor, namely, social conflict. The occurrence of rebellion will bring to various changes due to demands (Martono, 2014: 16-17).

In addition to internal factors, factors that come from outside (external) also cause social changes. These include: first, the occurrence of natural disasters or changes affect the condition of the natural environment, so this situation forces the society to flee to other regions. Migrating people to their new homes requires them to be able to adjust to new natural and environmental conditions. The adaptation process to the new environment is the beginning of social change. Second, war can trigger social change because the winning party will usually impose its ideology and culture on the losing party. Thus, the party that loses the war must accept the existence of the winning party. In reality, this behavior results in the loss of cultural elements from the losing party. If the influence caused by other cultures can be accepted without compulsion, then, this is known as the demonstration effect. However, when hatred occurs and triggers the rejection of other cultures, it is called cultural animosity. If a culture has a higher level than other cultures, an imitation process will emerge, which will then slowly shift the elements of the original culture.

In a society where a process of change occurs, some factors drive the process of change, namely: a) contacts with other cultures, b) an advanced formal education system, c) an attitude of respect for one's work and desires to progress, and d) tolerance, e) open system of society, f) heterogeneous population, g) public dissatisfaction with specific areas of life, h) future orientation, and i) the value that humans must always endeavor to improve their lives.

Conversely, the factors that hinder change include lack of relationships with other communities; the late science development; the attitude of a very traditional society; and firmly planted interests. Some other factors are the fear of shaking in cultural integration; prejudice against new or foreign things or closed attitudes; ideological barriers; customs or habits; and values that life is inherently wrong and cannot be fixed (Soekanto, 2009: 275-288).

It cannot be denied that any changes that occur will have an impact on society, including changes in social culture. These impacts can be positive or negative based on their effects on society. There are 
several positive impacts of social change. First, people are getting more comfortable and faster in completing their activities. Second, there has been increasing social integration due to various causes, such as disasters and social conflicts. Third, the quality of individuals (or communities) is getting better along with technological development in various fields. Fourth, social mobility is accelerating due to the improvement in the condition of society in various aspects of life. Fifth, human mindset is increasingly developing through cultural exchange and information exchange that can be done anytime and anywhere.

Furthermore, the negative impact of socio-cultural changes can be seen from: a) an increase in poverty which is a potential and indirect impact; $b$ ) the increase in the amount of unemployment because many technologies replace human labor, c) an increase in crime rates, d) the occurance social conflicts due to competition an increasing population, e) the increase in individuality due to reduced interaction due to technology; and f) environmental pollution due to technology created by humans (Martono, 2014: 26-27).

These positive and negative impacts can undoubtedly be felt when socio-cultural changes have occurred in a community. The impact can occur partly or even entirely depending on how much socio-cultural changes that occur affect the community.

\section{Description of Life and Existence of Suku Anak Dalam}

Suku Anak Dalam, also known as Orang Rimba, is one of the minority ethnic groups that live along with the forests of southern Sumatra in three provinces, namely Jambi, Riau, and South Sumatra. However, the most significant population of Suku Anak Dalam is in Jambi Province. Furthermore, Suku Anak Dalam is also the remaining ethnic minority in Asia who live as hunters and gatherers (Prasetijo, 2015: 1). Besides that, Suku Anak Dalam is also classified as one of the isolated communities of the four communities in Jambi Province. The other three groups are Orang Laut/Bajau, Talang Mamak, and Malay (Sager, 2008: 9).

Kubu and Orang Rimba are other names for Suku Anak Dalam. The term Kubu comes from the Malay language, which means fortress or shelter. Malays regard that the outside forces (such as Malay, Dutch, 
Indonesian) cannot control Kubu people if they settle in the wildwood. Sager defines that the term Kubu comes from the view of Muslim villagers about Orang Rimba as part of the wildwood to reject the entry of the social life and more Muslim Malays. For Sakai people (one of the Malay exonyms in the region), the term Kubu gives negative sense such as: 'belum madju'(uncultured or undeveloped), 'primitif'(primitive), 'kotor/jorok'(grubby), 'bau'(stinky), 'bodoh'(foolish), and 'belum punya agama'(no religion) (Sager, 2008: 5).

The existence of this minority tribe has been known since the 19th century. Studies and writings on this group have been carried out by researchers from the Netherlands under the supervision of the Dutch East Indies government. At that time, G.J. Van Dongen, besides being a researcher, also acted as a controller for Palembang Residency Area which also covered Jambi region. Dongen stated that Suku Anak Dalam is divided into 2 (two) categories, namely: civilized camps and wild camps. The civilized camp is a group that lives permanently, cultivates, and wants to communicate with village community through the intermediaries of Jenang. In contrast, the wild camp is a group whose lives move around in the forest and away from communication with the village community. (Rozelin, 2016: 4-5).

In the beginning, the Suku Anak Dalam community moved from one region to another in the forest and lived in groups. Based on their place of residence, Suku Anak Dalam community can be classified into three (3) settlement categories, namely: first, Suku Anak Dalam who live in the forest and move around. Second, Suku Anak Dalam that lived in the forest and settled. Last, Suku Anak Dalam whose settlements are close to the settlement of the general public. Furthermore, if observed based on their clothes, Suku Anak Dalam has undergone many changes. However, for people who still live in the forest and move around, they still maintain their traditional clothes with the following classification. First, for groups that live in the forest and move around, the use casual clothes, that is, by covering only certain parts by using a loincloth (cawat) for men and a kemban (female torso wrap) for women. Second, groups who live and settle in the forest dress according to their traditions, but sometimes also dress like outsiders, especially when they want to sell forest products or go to the market. Third, groups who live close to settlements outside the community (relocation) dress as 
the general community (village community) (Muntholib, 1995: 55) (Rozelin, 2016: 5).

Furthermore, when viewed ecologically, Suku Anak Dalam people live scattered in three different regions, namely: (1) the western part of Jambi Province (around Lintas Timur Sumatra road), (2) National Park area of Bukit Duabelas, in which they settle and wander in the lowland forest between Batanghari and Tembesi River, and (3) the northern part of Jambi Province, especially in National Park of Bukit Tigapuluh (the border of Riau and Jambi) (Takidin, 2014: 161).

Various theories explain the origin of Suku Anak Dalam. Eijkman Institute's research, as reported by the Popular Scientific Magazine, National Geographic (March 2006 Vol. 2, No. 3), concludes that Orang Rimba genetically and generally the Indonesian population who migrated in 60,000 BC originated from Africa. Van Dongen (1906: 1) said: "the only estimate is that the first inhabitants of these areas did not all want to surrender themselves to the Javanese forces that had ruled Palembang for about three centuries. Some of them (the first inhabitants of Jambi) fled into the hard-to-penetrate forest. There they were forced to wander and live miserably, leaving behind a more civilized way of life. Finally, they changed completely like the current situation". In the manuscript entitled "Een Bezoek Aan de Tamme Koeboes", Winter (1901: 7) wrote the story of Kubu people he met in Batu Licin: "lately they are often harassed by Jambi people, so long they have not been safe in their village; therefore, they live in the forest". It was further said "Jambi people first kidnapped several Kubu people, and were taken to their land to be slaves. After several Kubu people managed to escape and returned to the village, Jambi people came to sue them because they owed food and clothing, but they did not want to go back to Jambi and escape to the forest”. (Siagian, 2008: 4)

Another version of the origin of Orang Rimba summarized in the book "Rencana Pengelolaan Taman Nasional Bukit 12" (Jambi Natural Resources Conservation Center, 2004) contains some of the following information. First, they are the remnants of the Pagaruyung King of Minangkabau, namely, the laskar (warriors) who got lost on their way to Jambi when they returned to help the Queen of Jambi for battle. Warriors from Pagaruyung finally decided to stay and isolate themselves in the forest. Second, communities from Kubu Karambia 
Village, namely Kubu Karambia Village community group, are the members of the Kingdom of Pagaruyung. The latter refused to accept the teachings of Islam and then fled to the forest area in Jambi. The last is the descendants of a Bujang Perantau through marriage to a woman incarnating Kelumpang fruit. The two men later married and had offspring in the forest to bring down Kubu people now. So far, there has been no satisfactory review of the origin of Orang Rimba. (Siagian, 2008: 5)

In general, theories about the origin of the existence of Suku Anak Dalam can be divided into two groups. The first theory believes that Suku Anak Dalam people are the old Malay race as well as Dayak, Sakai, Nias, Mentawai, Toraja, Sasak, Papua, and Batak that constituted the first wave migrating to Sumatera. The second theory comes from the folklore, which states that Suku Anak Dalam came to an exile area for some reasons. However, according to Berta, Orang Rimba claimed that they were native to Sumatra and originated from the Minangkabau or the Minangkabau from them (Berta, 2014: 10).

The existence of Suku Anak Dalam communities in Jambi Province shows a picture of the different origins of their ancestors. Muchlas concluded that Suku Anak Dalam came from three derivatives namely South Sumatera descendants of Minangkabau who are in Bungo Tebo District; most of Mersam District (Batanghari District); and the descendants of Jambi indigenous people in Air Hitam area, Sarolangun Regency (Sagala et al., 2018: 244).

In addition to some of the statements above, there is a new statement from Majalah Tempo about the origin of Suku Anak Dalam in Jambi Province which is different from the hereditary story within Suku Anak Dalam family. Anderbeck (2010: 8) explained that Suku Anak Dalam community was included in the Melayu Tua (Old Malay) group who came from Yunan, China who then fled to the forest, while the Melayu Muda (Young Malay) group was a Malay community living on the Sumatra coast. (Rozelin, 2016: 45).

Suku Anak Dalam is known as a community group with a nomadic lifestyle. Migration that they do from one region to another is very dependent on the availability of food sources and forest resources. This nomadic habit makes the existence of Suku Anak Dalam divided into several large groups spread across 6 (six) districts in Jambi Province, 
namely Merangin, Sarolangun, Batanghari, Tanjung Jabung Barat, Tebo, and Bungo Regencies. Furthermore, each of these groups is divided into smaller groups led by a Temenggung (Central Statistics Agency of Jambi Province, 2011: 6). The basis for forming this group refers to the uxorilocal tradition, where newly married couples settle near their wife's relatives. This is because, for Suku Anak Dalam, women are the basis of their autonomy. That is why women are very guarded and especially for the young ones. The are very protective to themselves from outsiders (Central Statistics Agency of Jambi Province, 2011: 23).

There are many studies which state that the kinship line adopted by Suku Anak Dalam is matrilineal (the tracing of descent through the female line). This opinion was confirmed by Lowie, that a sign of matrilineality; that they all descend from one common ancestor. Lowie continued, Suku Anak Dalam is the ancestors of the Minangkabau who are known for the matrilineal society (Berta, 2014: 12).

Referring to data from the Social Office of Jambi Province in 2018, the most significant number of Suku Anak Dalam is in Sarolangun District with a population of 1,971 people spread across seven subdistricts and ten villages. The second largerst population is in Batanghari Regency with a population of 1,816 people spread in two districts and five villages. The next is Tebo Regency with a population of 1,609 people spread in 5 districts and 12 villages. Further, the distribution area of Suku Anak Dalam is located in Merangin District with a population of 1,244 people spread in 6 subdistricts and 16 villages (Documentation, Social Office of Jambi Province, 2018).

Based on the population, the most significant number of Suku Anak Dalam communities are in Sarolangun, Batanghari, Tebo, and Merangin Regencies. This is because the area is a forest area within the scope of Bukit Dua Belas National Park. Suku Anak Dalam uses the forest as a source of their livelihood. Sager states that the lives of Orang Rimba are based around forests or swidden areas which keep changing from season to season (Sager, 2017: 81).

Suku Anak Dalam can be classified into three groups based on the categories of wandering, temporary residence, and sedentary. Each group has characteristics that are different from one another. It can be seen as the following table (Mailinar and Nurdin, 2013: 251-252). 
Table 1. Suku Anak Dalam in Wandering Category

\begin{tabular}{|cll|}
\hline NO & \multicolumn{1}{|c|}{ CATEGORY } & \multicolumn{1}{c|}{ CHARACTERISTICS } \\
\hline 1. & Wandering (Melangun) & $\begin{array}{l}\text { For 2-4 years, participants are all family members with } \\
\text { a radius of a distance of 75 kilometers }\end{array}$ \\
\hline 2. & Traditional Leader & $\begin{array}{l}\text { Temenggung, Depati, Mangku, Menti, and Debalang } \\
\text { Batin }\end{array}$ \\
\hline 3. & Basale & $\begin{array}{l}\text { Viewed as a sacred ceremony, maintained and should } \\
\text { not be watched by outsiders }\end{array}$ \\
\hline 4. & Field (Huma) & No farming, no culture to cultivate the land \\
\hline 5. & Residence & Not having a permanent residence \\
\hline 6. & House (Sadung) & Very simple, as a shelter \\
\hline 7. & Group & Small group based on genealogy \\
\hline 8. & Livelihood & Hunting and gathering \\
\hline 9. & Social interaction & Limited and closed, through Jenang or landlady \\
\hline 10. & Property & Sarong, spear, and machete \\
\hline 11. & Belief & Animism, Dynamism, Polytheism \\
\hline
\end{tabular}

Table 2. Suku Anak Dalam in the Temporary Residence Category

\begin{tabular}{|cll|}
\hline NO & \multicolumn{1}{|c|}{ CATEGORY } & \multicolumn{1}{c|}{ CHARACTERISTICS } \\
\hline 1. & Wandering (Melangun) & $\begin{array}{l}\text { For 3-6 months, participants are all family members, } \\
\text { radius } \pm 25 \text { kilometers }\end{array}$ \\
\hline 2. & Field (Huma) & $\begin{array}{l}\text { Beginning to open fields, broad fields / huma } \pm 1 / 4 \\
\text { hectare }\end{array}$ \\
\hline 3. & Traditional Leader & Some structures have been lost \\
\hline 4. & Basale & $\begin{array}{l}\text { Not sacred and maintained, and can be watched by } \\
\text { outsiders }\end{array}$ \\
\hline 5. & Residence & $\begin{array}{l}\text { Starting settling in a particular time, location in } \\
\text { huma/field }\end{array}$ \\
\hline 6. & House (Sadung) & Very simple, as a shelter \\
\hline 7. & Group & $\begin{array}{l}\text { Large groups and began to join with other ethnic } \\
\text { groups }\end{array}$ \\
\hline 8. & Livelihood & Gathering \\
\hline 9. & Social interaction & Open \\
\hline 10. & Property & Home, garden, vehicle \\
\hline 11. & Belief & Animism, Dynamism, some others Islam \\
\hline
\end{tabular}


Table 3. Suku Anak Dalam in Sedentary Categories

\begin{tabular}{|cll|}
\hline NO & \multicolumn{1}{|c|}{ CATEGORY } & \multicolumn{1}{c|}{ CHARACTERISTICS } \\
\hline 1. & Wandering (Melangun) & No wandering \\
\hline 2. & Field (Huma) & Having a rubber and palm plantation \\
\hline 3. & Traditional Leader & Some structures have been lost \\
\hline 4. & Basale & $\begin{array}{l}\text { Not sacred and maintained, and can be watched } \\
\text { by outsiders }\end{array}$ \\
\hline 5. & Residence & Settling in settlements, villages/hamlets \\
\hline 6. & House (Sadung) & Various \\
\hline 7. & Group & $\begin{array}{l}\text { Large groups and begin to join with other } \\
\text { ethnic groups }\end{array}$ \\
\hline 8. & Livelihood & $\begin{array}{l}\text { Farms, rubber plantations, wage labor, } \\
\text { woodworker (tapping rubber) }\end{array}$ \\
\hline 9. & Social interaction & Open \\
\hline 10. & Property & Home, garden, vehicle \\
\hline 11. & Belief & Islam \\
\hline
\end{tabular}

Based on the above characteristics, Suku Anak Dalam in Sikaladi and Lubuk Kayu Aro Villages, Muaro Jambi Regency, and Karang Berahi Village, Merangin Regency used as the focus of this study belong to the sedentary category. They have long embraced Islam, settled and mingled with the surrounding society. Besides, their livelihood is gardening, while Suku Anak Dalam in the Mentawak Village, Merangin Regency, is still classified as a temporary residence category. They still adhere to the beliefs of their ancestors. In their daily lives, they have settled, but only for a while. Moreover, under certain conditions, such as a family member who suffers from severe illness, this community of Suku Anak Dalam still practices the tradition of wandering.

The 2010 Jambi Province Population Census compiled a picture of the religion adopted by Suku Anak Dalam. As many as 3.46\% of Suku Anak Dalam embraced Islam, $10.39 \%$ adhered to Christianity, and the largest one adhered to the religion of the Ancestors, which amounted to $86.15 \%$. Specifically for Suku Anak Dalam in the Merangin Regency area in 2010, 15 people adhered to Islam, 163 people adhered to Christianity, and 687 people adhered to their ancestors'. Islam and Christianity adopted by Suku Anak Dalam are caused by 
frequent interactions with residents outside the forest, such as social interactions, economic interactions, and empowerment programs both by the Government and Non-Governmental Organizations (Central Statistics Agency of Jambi Province, 2011: 22-24).

Related to this, the Suku Anak Dalam community in the villages of Sikaladi, Lubuk Kayu Aro, and Karang Berahi have embraced Islam. Suku Anak Dalam community in Karang Berahi Village in their worship practices is still not consistently practicing Islamic teachings (Rahman, interviewed July 27, 2019). Meanwhile, the Suku Anak Dalam community in Mentawak Village still holds to beliefs according to the teachings of their ancestors (Sikar, interviewed June 29, 2019).

When explored further, Suku Anak Dalam living in Karang Berahi Village, Merangin Regency, is not Suku Anak Dalam originally from the area, but they are from Bukit Dua Belas area. Likewise, Suku Anak Dalam in the Mentawak Village, Nalo Tantan District who came from the Pamenang region. Based on interviews with Sitai and Pengendum Tampung, their migration was motivated by several factors, namely the interaction with the surrounding population, marriage with people outside the Suku Anak Dalam community, and religious conversion (Sitai, interviewed June 28, 2019).

\section{The Inheritance System of Suku Anak Dalam: The Struggle between Islamic and Customary Law}

In various activities of life, the Suku Anak Dalam community is strongly influenced by the legal rules applied in the form of selokoseloko (the term, a proverb which is a customary rule) explicitly used as a life guide by leaders, especially Tumenggung in making a decision. Seloko also serves as a guideline in speaking and behaving in social life. Seloko includes bak emas dengan suasa ('like the gold and copper': the difference between the expensive and cheap value), bak tali berpintal tigo ('like a three spinning rope': togetherness becomes strength), di mano biawak terjun di situ anjing telulung ('where lizard plunges, there the dog barks': where we do wrong, there is the custom used), di mano bumi dipijak di situ langit dijunjung ('where the earth is grounded, there where the sky is upheld': where we are, there is the custom that we uphold, we adapt), bini sekato laki dan anak sekato bapak ('a wife 
follows husband, son follows father': that in family affairs the role of a man or father is very prominent) (Tarib, 2012: 5).

For Suku Anak Dalam people, the custom is not only tradition and norms, but it is also about the ways how they organize their lives traditionally. Custom is used and exists in all social interactions. Despite the belief, they have faithfully converted to Islam. Still, to remain recognized as part of the Orang Rimba community, they have to have Orang Rimba religion, unless they cannot live in the delom (inside) community. Though Orang Rimba uses the term agama (religion), its term is used to describe their practices (Berta, 2014: 47).

Even though they have converted to Islam, in practice, Suku Anak Dalam still dominantly uses customary law in the implementation of the inheritance system. This fact is caused by the limited knowledge of Suku Anak Dalam, who has converted to Islam on Islamic teachings. In general, they know that Allah is God, Muhammad is the Prophet, and the Qur'an is the Holy Scriptures. However, in practice, Islamic teachings occur a mixture of Islamic and customary law. It can be seen in the marriage ordinance, such as about people who can be married and inheritance distribution (Mailinar, 2013: 263; Sagala et al., 2018: 244).

The older groups of Suku Anak Dalam assume that there is no conflict between the values of the traditions that they do with Islam. It might fade their religious status if these tendencies continue. Suku Anak Dalam in the folklore is believed as Palembang descendant, and they may be Muslim. In 1812, Palembang was conquered by the Netherlands for the first time. Palembang Islamic Sultanate founded and ruled it in 1659. Therefore, it can be assumed that the majority of Palembang's inhabitants embraced Islam, wherein Royal traditions, the King's religion was the State religion.

Nevertheless, Marsden states that the inland communities of Sumatra are generally devout Muslims who do not know the Islamic doctrine well. Meanwhile, after the advent of the Islamic reform movement, urban areas experienced rapid development of knowledge, especially during the 17 th and 18 th centuries. Orang Rimba, who was sequestered, understands Islam stagnantly. This can lead to the fading of the Islamic identity of Orang Rimba so that after hundreds of years, their generation no longer knows about Islam (Marsden, 2013: 246340); (Sagala et al., 2018: 244). 
However, in several aspects, this practice is in line with Islamic inheritance law. It can be seen in: first, the use of Seloko waris bejabat khalifah bejunjung ('the heirs are held, the caliph is upheld'), as a rule in the distribution of inheritance. It is intended that Suku Anak Dalam must uphold what has been passed down by the previous caliph or leader, and the child as heir must be welcomed. It means that inheritance is given to the rightful heirs, and the main heir is the child. Thus, the heir group is more focused on the nuclear family only, namely children and wives.

This situation may be a reflection of the implementation of customary law which makes the heir child as the main heir and can close the heir's parents. It is certainly not in line with Islamic inheritance law, because the heir's parents are heirs who have never been blocked in their entirety by other heirs. However, if it turns out that in reality, the parents of the testator then give up their portion to be handed over to the heir's child (grandchild), then that is not a problem.

Second, in terms of the time, inheritance distribution can be done in 2 (two) ways, namely: dividing the assets before the testator dies and after the testator dies. Distribution of inheritance can be done since the seventh days after the death of the testator. It is intended so that all other people's rights attached to the assets are fulfilled/settled, including the debt, or will of the heir before the distribution of inheritance is carried out.

The time of inheritance distribution, which is carried out before someone's death, is considered a gift (hibah). In principle, this does not contradict the Islamic inheritance law as long as the hibah does not harm the rights of other heirs, such as not giving hibah or will more than one-third of the total assets.

Related to the relationship between hibah and inheritance, the Compilation of Islamic Law, Article 211, states that " hibah from parents to their children can be counted as an inheritance." When analyzed further, Article 211 of the Compilation of Islamic Law contains aspects of ' urf because after seeing the texts (nash), both the Qur'an and the Hadith, no texts are found that indicate the calculation of parent hibah to children as an inheritance.

The term "can" in that article does not mean imperative (must). Still, it is one alternative that can be taken to resolve inheritance 
disputes (Ibin: 6), as long as the heirs are not concerned about hibah that have been received by some of the heirs. However, if some heirs are concerned, then hibah can be counted as an inheritance.

Hibah is a way out of inheritance distribution to avoid conflicts occurring in most of the cases caused by the existence of people prevented from receiving inheritance due to religious differences, adopted children, or differences in the part of each heir. Some society often sees the latest as the symbol of injustice. Although this is seen as the ambiguous attitude of Muslims in the face of inheritance, the use of hibah is considered as manipulation to reject Islamic inheritance law. One form is the desire of the grantor (wahib) to give his wealth to the recipient of hibah in the amount he wants to avoid other legal provisions that limit the number of assets that may be accepted by the recipient of hibah. It is what Munawir Syadzali calls hilah al sharia.

Concerning the inheritance distribution carried out after seven days of the death of the testator, the inheritance law is known as the delay in the distribution of inheritance. The intention is to delay the inheritance distribution, which is due from the testator's death until its distribution. Related to the time lag between the death of the testator and the distribution of inheritance, it makes the differences between Islamic law and customary law. According to Islamic law, the distribution of inheritance can be done after the testator dies. In contrast, according to customary law, the distribution of inheritance is carried out after the seventh, forty, and hundredth days of commemoration.

In the next stage, the distribution of inheritance begins with sorting out the assets carried by the wife and inheritance from joint search results before being handed over or distributed to family members. The wife's assets will be returned to the wife, while the assets obtained together are divided equally. Nevertheless, if they still have children, then the assets will go to the children (Rahman, interviewed July 27, 2019). In this context, it appears that Suku Anak Dalam has become acquainted with the division of assets, which is inherited assets obtained before the marriage and joint-searched assets, then divided into inheritance.

This division of assets is in line with the provisions of customary inheritance law, and Compilation of Islamic Law. According to customary law, as long as a couple does not yet have offsprings, livelihoods can be separated. Nevertheless, if a married couple already has children, 
the source of livelihood is mixed (Wicaksono, 2011: 7). Furthermore, original assets are all assets that are controlled and owned by the heir from the first moment of entering the marriage and possibly increasing until the end of his life. In the Compilation of Islamic Law, Article 171 letter e of the Compilation of Islamic Law (KHI) states that there are two types of acquisition of inheritance, namely inheritance and joint assets. The realization of the inheritance distribution implementation is half of the joint assets regulated in Article 96 paragraph (1) and Article 97, added to the inheritance inherited assets. After that, the assets are issued for use relating to the heir's self, including the implementation of burial.

Related to the inherited form of inheritance, Suku Anak Dalam also knows the distribution of great heirlooms and low heirlooms. Great heirlooms are assets inherited from ancestors, may not be sold, while low heirlooms are the results of joint income of a husband and wife and may be traded. This grouping of assets is due to the kinship system adopted by the Suku Anak Dalam community in a matrilineal system, following the kinship system prevailing in the Minangkabau community. For them, the group of great heirlooms is immovable property, that is, houses or land, while low heirlooms are movable property in the form of cloth, clothes, and motorized vehicles.

This system of inheritance is known in the customary law as a system of collective (shared) inheritance. According to this inheritance system, the heirs may not own personal inheritance but are allowed to use, cultivate, or process and enjoy the results. In general, this collective inheritance system applies to ancestral inheritance called "heirlooms," in the form of land (agriculture) or heirlooms, such as great heirlooms of land, rice field, houses, which are controlled by Mamak head of inheritance and used by nephews together.

Distribution of inheritance to children can be done if their children are married. As long as the children are not married, the wife has a role in holding the inheritance. After that, the inheritance portion for the wife from the remaining assets that have not been shared is determined. However, in practice, the Suku Anak Dalam community usually divides the inheritance by equal portions to all existing heirs. The process of distributing inheritance usually involves only family members. However, it is not uncommon for Tumenggung or Indigenous Leader 
to intervene in a meeting of the distribution of one's inheritance (Sitai, interviewed June 28, 2019).

In principle, the distribution of assets like this follows the provisions of customary inheritance law. Customary inheritance law recognizes the principle of equality and togetherness of rights; that is, each heir has the same position as the person entitled to inherit his inheritance, balanced between the rights and obligations for each heir to obtain the inheritance. Different from Islamic law that recognizes the number of specific for each heir.

\section{Shifting of Social Values in the Inheritance System of Suku Anak Dalam}

In its development, the customary law system that applies to the community can change. Changes in customary law can occur due to the influence of events and circumstances of life. However, changes to customary law can not be done suddenly because given the nature of customs that are considered sacred and have been applied for generations since time immemorial. The rules in the customary law are introduced and applied first by the customary holders in certain situations in daily life so that indigenous people will not realize changes. Besides, this change is also supported by the unwritten customary law, which causes customary law to be able to adjust to new situations. This change in customary law also embraces various forms of shifts in the inheritance system among the Suku Anak Dalam community that have embraced Islam.

The religious conversion that took place in the Suku Anak Dalam community has implications for shifts in various ways, including in their inheritance system. The form of shifting social values is seen in:

\section{a. Shifting of Religious Values}

Some forms of shifting in religious values in the practice of the inheritance system of Suku Anak Dalam include: first, the process of organizing deceased bodies. For Suku Anak Dalam, if a family member dies, the body is placed in a hut built in the forest and then left in a certain radius for several months to three years depending on the person who died and the cause of death known by the term melangun (Berta, 
2014: 49). At present, Suku Anak Dalam people who have converted to Islam organize the deceased bodies under the rules in Islamic law (Rahman, interviewed July 27, 2019).

Second, the shift is seen in those who play a role in dividing the inheritance. Before converting to Islam, the distribution of inheritance was arranged by the eldest child to the younger siblings after the parents (heir) died. Inheritance is given to the heirs (children) who are already mature, even though they are not married. Furthermore, the remaining inheritance must also be given to his grandfather, grandmother and uncle, if there is a good relationship between the oldest child and others. Likewise, if the heir does not have children, the heirs will be relatives of the heir.

Along with the times, these provisions have changed. The oldest child is not required to give heirs to the grandfather, grandmother, or uncle. However, after converting to Islam, wives have a role in holding the inheritance as long as their children are not married. The inheritance is given to children if they are married. After that, the inheritance portion for the wife from the remaining assets, which have not been given, is determined. In this case, the distribution is adjusted to the contents of the testament. The process of awarding inheritance through this testament is also a form of change in the process of an inheritance among Suku Anak Dalam. Thus, grandfather and uncle have a role in showing the contents of the testator's will to the heirs. Furthermore, the process of distributing inheritance only involves family members. However, Temenggung plays an essential role in resolving a conflict related to the distribution of inheritance, even though there is a testament (Sitai, interviewed June 28, 2019).

Third, for Suku Anak Dalam, the heirs include children as the main heir, wife, father, mother, and brother. Nevertheless, later, the heir group is more focused on the central family only, namely children and wife, while the father, mother, and brother are no longer the heir group who must receive the inheritance.

\section{b. Shifting of Economic Values}

The shift in economic value can be seen in: first, changes in the form of inheritance. Before becoming a Muslim, assets that could be 
inherited are in the form of valuable objects and daily used objects, such as clothes, crockery, cauldron, keris (traditional knife), and machetes. In the current development, on the other hand, the inheritance is in the form of cars, land, homes, and others. In practice, if a child asks a parent for certain assets such as a car, land, or house, then only that property will be obtained by the child after the parent dies.

Second, in the classification of inheritance regarding inherited assets, Suku Anak Dalam in Karang Berahi Village also recognizes the distribution of assets into high and low inheritance. Great heirlooms are assets passed down from generation to generation, may not be sold, while lower heirlooms are assets from the search for husband and wife and may be traded. In the past, great inheritances were keris and gold. On the other hand, low inheritances are pots and machetes. However, this later changed. At present, Inheritance classified as high inheritance property includes lands, while the low includes clothes and vehicles.

\section{c. Shifting of Political Values}

The form of shifting political values in the inheritance system of Suku Anak Dalam is seen in: First, the change in the role of children and wives in the process of inheritance distribution. In the past, inheritance distribution was arranged by the eldest child to younger siblings after the parents (heir) died. However, now, the wife has the role of keeping the inheritance as long as their children are not married. This is the provisions in the Suku Anak Dalam Karang Berahi community. The inheritance is only given to children if they are married, while related to the distribution, it is adjusted to the testament.

Second, there is Tumenggung's involvement in the distribution of inheritance. In the distribution of inheritance, previously, it only involved the nuclear family of the testator. However, due to the frequent occurrence of conflicts among heirs, Tumenggung and Pemangku Adat play roles in the distribution of inheritance (Sikar, interviewed June 29, 2019).

In summary, the three forms of this value shift can be seen in the following table: 
Table 4. Forms of Value Shifts in the Inheritance System of In-Child Tribes

\begin{tabular}{|c|c|c|c|}
\hline Value Shift & Form & Before Muslim & Muslim \\
\hline \multirow[t]{2}{*}{ Religion } & $\begin{array}{l}\text { The process } \\
\text { of organizing } \\
\text { deceased bodies }\end{array}$ & $\begin{array}{l}\text { Melangun (leaving the } \\
\text { corpse in a hut in the } \\
\text { middle of a forest for } \\
\text { several months to } 3 \text { years). }\end{array}$ & $\begin{array}{l}\text { The organization of the } \\
\text { corpses follows the rules in } \\
\text { Islamic law. }\end{array}$ \\
\hline & $\begin{array}{l}\text { Inheritance } \\
\text { Process and } \\
\text { Distribution of } \\
\text { Inheritance }\end{array}$ & $\begin{array}{l}\text { 1. The eldest son } \\
\text { arranged the } \\
\text { distribution of assets } \\
\text { to his younger siblings } \\
\text { after the death of the } \\
\text { heir. } \\
\text { 2. Inheritance is given } \\
\text { to heirs (children) } \\
\text { who are adults, even } \\
\text { though they are not } \\
\text { married. }\end{array}$ & $\begin{array}{l}\text { 1. Wives have the role of } \\
\text { holding the inheritance } \\
\text { as long as their children } \\
\text { are not married. } \\
\text { 2. The portion of } \\
\text { inheritance for a wife } \\
\text { is determined from the } \\
\text { remaining assets that } \\
\text { have not been given. } \\
\text { 3. The distribution is } \\
\text { adjusted to the contents } \\
\text { of the will. }\end{array}$ \\
\hline & Heir & $\begin{array}{l}\text { Heirs include children as } \\
\text { main heirs, wives, fathers, } \\
\text { mothers, and brother of } \\
\text { the heirs. }\end{array}$ & $\begin{array}{l}\text { The heirs are more focused } \\
\text { on the nuclear family only: } \\
\text { children and wife, while } \\
\text { the father, mother, and the } \\
\text { heir's brother are no longer } \\
\text { a group of heirs who must } \\
\text { receive the inheritance. }\end{array}$ \\
\hline \multirow[t]{2}{*}{ Economy } & $\begin{array}{l}\text { Forms of } \\
\text { Inheritance }\end{array}$ & $\begin{array}{l}\text { Inheritance in the form } \\
\text { of valuable objects and } \\
\text { objects are commonly } \\
\text { used daily, such as cloth, } \\
\text { crockery, cauldron, keris, } \\
\text { and machetes. }\end{array}$ & $\begin{array}{l}\text { Inheritance in the form of a } \\
\text { car, land, and house. }\end{array}$ \\
\hline & $\begin{array}{l}\text { Classification of } \\
\text { Inheritance }\end{array}$ & $\begin{array}{l}\text { High inheritance: } \\
\text { kris and gold. On the } \\
\text { contrary, low inheritance: } \\
\text { stoneware and machete. }\end{array}$ & $\begin{array}{l}\text { High inheritance is land, } \\
\text { while the low ones are cloth } \\
\text { (clothes) and motorcycles. }\end{array}$ \\
\hline \multirow[t]{2}{*}{ Politics } & $\begin{array}{l}\text { Changes in the } \\
\text { role of children } \\
\text { and wife in the } \\
\text { distribution of } \\
\text { inheritance }\end{array}$ & $\begin{array}{l}\text { The eldest child arranges } \\
\text { the distribution of } \\
\text { inheritance to his younger } \\
\text { siblings done after the } \\
\text { death of the parents } \\
\text { (heir). }\end{array}$ & $\begin{array}{l}\text { Wives have a role in } \\
\text { holding the inheritance as } \\
\text { long as their children are } \\
\text { not married. }\end{array}$ \\
\hline & $\begin{array}{l}\text { The } \\
\text { Temenggung's } \\
\text { involvement in } \\
\text { the distribution } \\
\text { of inheritance }\end{array}$ & $\begin{array}{l}\text { It only involves the } \\
\text { nuclear family of the heir. }\end{array}$ & $\begin{array}{l}\text { Temenggung and Pemangku } \\
\text { Adat also play a role in the } \\
\text { distribution of inheritance. }\end{array}$ \\
\hline
\end{tabular}




\section{The Factors Influencing the Shifting of Social Values in the Inberitance System of Suku Anak Dalam}

The shift in social values that occur in the inheritance system of Suku Anak Dalam is influenced by several factors. The first factor is religion. The shift in the implementation of the inheritance among Suku Anak Dalam is caused, among other things, by religious conversion from the previous beliefs, animism and dynamism, to Islam. Customary law rules previously applied as a whole slowly began to be abandoned, and the people start to follow the rules of Islamic law.

The second factor is social interaction. Suku Anak Dalam people hold customs. For them, the customs is not only a law, but also rules, restrictions, social organization, beliefs/religion, and cosmology. Custom is inherited through oral traditions, myths, and observations, and is monitored and guarded by Mengku (Indigenous Stakeholder). Custom is an important matter. So if someone does not respect and follow customs, it will impact on the hard life, even endanger the community. Vice versa, respecting, and the following custom can give the people a safe and useful life in their community (Berta, 2014: 44-55). However, social interactions with migrant communities contribute to changes in mindset, even beliefs. Sitai and Mengku Rahman acknowledged it.

The third factor is migration. The Suku Anak Dalam community commonly does population migration from one area to another. According to Temenggung Tarib, when referring to oral history, the existence of Suku Anak Dalam/Orang Rimbo in Jambi was partly due to migration from Pagaruyung to look for better livelihoods because of insecure and inconducive situations, as well as an inadequate food supply. Even today, Suku Anak Dalam are seminomadic because of their habit of moving from one place to another. This migration process was carried out for several reasons, including: to make a living, melangun (eliminate sadness because one family member died), avoid the enemies, or open a new field (Tarib, 2012: 2-3). Besides, according to Sitai, conversion to Islam is also a factor that drives them to migrate from Bukit Dua Belas to Karang Berahi Village, Merangin. They, even now live permanently and side by side with the surrounding community. This, then, influenced changes in the inheritance system among Suku Anak Dalam. 
The fourth factor is marriage. Marriage with people outside the Suku Anak Dalam community contributes to the changes. Based on the interviews with Pengendum Tampung, Suku Anak Dalam in Bukit Dua Belas, the region where they come from adheres to a matrilineal kinship system (connecting kinship through the female line) that prioritizes the distribution of inheritance to women. However, due to marriages with people outside Suku Anak Dalam (originating from Java), the kinship system shifted to parental that connects the kinship line between the men and women (Tampung, Interviewed July 19, 2019).

The fifth factor is related to the economy. Because Suku Anak Dalam people depended their lives on the nature/forest, they did not have time to think about owning or even storing assets because all of the needs are available in the forest. This makes the amount and form of inherited assets were not much. This is different from the current conditions, where Suku Anak Dalam has settled down. They have gardens, lands, houses, and even vehicles so that the form and amount of inherited assets are more numerous and varied.

The sixth factor is education. For Suku Anak Dalam, education is considered as damaging to traditions that they have been holding up. However, the rapid development of technology and information requires the Suku Anak Dalam community to get an education. Besides, the process of social interaction with outsiders also influences their perspective on the urgency of education, including religious education. In the villages of Sikaladi and Lubuk Kayo Aro, Mestong Subdistrict, Muaro Jambi Regency, the children of Suku Anak Dalam community have attended school, and some even will have a university education. Likewise, women are actively involved in the Ta'lim Assembly.

The seventh factor is related to conflict avoidance. Inevitably, the distribution of inheritance often leaves conflict among family members. This also happens in the Suku Anak Dalam community. According to Sikar, in the past, the inheritance was only done by the heir's family without involving outsiders. However, this led to the occurrence of conflict. Therefore, to minimize the emergence of conflict, at this time, Tumenggung is always involved in the distribution of inheritance (Sikar, interviewed June 29, 2019). 


\section{Conclusions}

The inclusion of Islamic teachings has a considerable influence on the changing order of life of the Suku Anak Dalam community. This change also covers provisions related to inheritance systems. However, in practice, there is a dualism in the application of inheritance law, namely Islamic inheritance law and customary inheritance law. Although having converted to Islam, it seems that the use of customary inheritance law is more dominant than Islamic law. It cannot be denied that the existence of pluralistic inheritance law in Indonesia also influences this.

Furthermore, the changing process of the inheritance system that occurred among Suku Anak Dalam also influences the shifting of religious, economic, and political values. The changes start from the process of organizing deceased bodies; the process, and the distribution of inheritance; to the form and classification of inheritance. Several factors influence this shift include the conversion of religion to Islam, social interaction with migrant communities, migration from one region to another, and education.

\section{Acknowledgment}

This article is based on research funding by UIN Sulthan Thaha Saifuddin Jambi under the project "Pergesearan Nilai Agama, Ekonomi, dan Politik dalam Sistem Kewarisan Suku Anak Dalam" (Religious, Economical, and Political Values Shifting in Inheritance System of Suku Anak Dalam) with contract number B-100/Un.15/ LPPM/L.II.2/05/2019. Furthermore, we also thank Mr Asman Hatta and $\mathrm{Mr}$ Rozali, who have been willing to accompany and facilitate us to conduct observations and interviews with Tumenggung (Chief of the Tribe) and Suku Anak Dalam community. Likewise, Willy, Josir, Dila, and Cici helped us collecting data. Last, we would also like to thank Indah Etika for her willingness to edit the grammar.

\section{References}

Ali, A. (2012). Menguak Teori Hukum dan Teori Peradilan. Jakarta: Kencana Prenada Media Group.

Anderbeck, K. (2008). Malay Dialects of Batanghari River Basin (Jambi, Sumatera), SIL-International e-Books, Library of Congress Catalog Number: 2007942663. 
Berta, A.E.V. (2014). People of The Jungle, Adat, Women, and Change among Orang Rimba, Thesis, University of Oslo.

Boty, M. (2015). Agama dan Perubahan Sosial (Tinjauan Perspektif Sosiologi Agama), Istinbath 15(4): 35-50.

Central Statistics Agency of Jambi Province. (2011). Profil Suku Anak Dalam (SAD), Hasil Sensus Penduduk 2010, Jambi.

Hidayati, R. (2016). Pergeseran Sistem Perkawinan dan Perceraian Pada Suku Anak Dalam. Al-Risalah 16(1): 151-168.

Mailinar and Nurdin, B. (2013). Keagamaan Suku Anak Dalam di Dusun Senami III, Desa Jebak, Kabupaten Batanghari, Jambi, Jurnal Kontekstualita 28(2): 247-271.

Marsden, W. (2013). History of Sumatra (Sejarah Sumatra). trans. Tim Komunitas Bambu. Jakarta: Komunitas Bambu.

Martono, N. (2014). Sosiologi Perubahan Sosial. Jakarta: Raja Grafindo Persada.

Prasetijo, A. (2015). Orang Rimba, True Custodian of The Forest, Alternative Strategies and Actions in Social Movement against Hegemony. Jakarta: Indonesia Center for Sustainable Development.

Rimawati, C. (2015). Pergeseran Hukum Waris Adat di Kalangan Masyarakat Melayu di Kecamatan Nongsa Propinsi Kepulauan Riau, Premise Law Jurnal $4: 1-15$.

Rozelin, D. (2016). Dialektologi Orang Rimba di Pulau Sumatera, Dunia Linguistik yang Terpinggirkan. Yogyakarta: Idea Press.

Sager, S. (2008). The Sky is our Roof, the Earth our Floor, Orang Rimba Customs and Religion in the Bukit Duabelas Region of Jambi, Sumatra. PhD Dissertation, The Australian National University.

Sager, S. (2017). The Stalk that Supports the Flower: Orang Rimba Kinship, Marriage, and Gender in Jambi Sumatra, Oceania 87(1): 78-95.

Sagala, I., et al., (2018). The Comprehension of The Orang Rimba Muslim Converts Towards The Quran. In Proceeding of Advances in Social Science, Education and Humanities Research, , International Conference on Qur'an and Hadith Studies (ICQHS 2017) 13(7): 242-248

Siagian, M. (2008), Orang Rimba Dalam dan Orang Rimba Luar, Studi Tentang Dampak Deforestatsi Pada Mode Produksi, Mode Reproduksi, dan Hubungan Suku Bangsa di Jambi, Thesis, Gadjah Mada University.

Soekanto, S. (2009). Sosiologi Suatu Pengantar. Jakarta: Raja Grafindo Persada.

Takidin. (2014). Nilai-nilai Kearifan Budaya Lokal Orang Rimba (Studi pada Suku Minoritas Orang Rimba di Kecamatan Air Hitam Provinsi Jambi, Sosio Didaktika 1(2): 161-169.

Tarib. (2012). Hutan Adalah Rumah Dan Sumber Penghidupan Kami, The Witness from Tumenggung Tarib "Orang Rimbo" Jambi Province, Presented at the Case Session Number 35/PUU-X/2012 regarding the Testing of Law 
Number 41 of 1999 concerning Forestry Against the 1945 Constitution of the Republic of Indonesia in the Constitutional Court of the Republic of Indonesia.

Tarigan, A. A. (2014). Pelaksanaan Hukum Waris di Masyarakat Karo Muslim Sumatera Utara, Ahkam 14(2): 199-212.

Van Dongen, G.J. (1906). Tambahan Pengetahuan Tentang Kubu Ridan. Naskah Terjemahan, Museum Adat Jambi.

Wicaksono, F. S. (2011). Hukum Waris Cara Mudah dan Tepat Membagi Harta Warisan. Jakarta: Visimedia.

Winter. (1901). Een Bezoek Aan de Tamme Koeboes, dalam De Indische Ginds. Staat-en Letterkundig Maadschrift, Drie en Twintigste Jaargang. Amsterdam: J.H. de Bussy. Translated by Ny. S. Hertini Adiwoso dan Budi Prihatna. Naskah Terjemahan, Museum Adat Jambi.

Yunita, M. R and La Kahija, Y. F. (2014). Makna Menjadi Muslim Pada Suku Anak Dalam di Taman Nasional Bukit Dua Belas Kabupaten Sarolangun, Provinsi Jambi. Empati 3 (1): 1-10. 